\title{
The role of the Director Zmago Slokan in the development of Maribor General Hospital in the first period after the Second World War (1953-1970)
}

\author{
Gregor Pivec
}

Received: 7 July 2015 / Accepted: 17 November 2015 / Published online: 11 December 2015

(C) Springer-Verlag Wien 2015

Summary The author explores and explains the role of the director of Maribor General Hospital in the first period after Second World War. The period was problematic on account of the difficult economic situation and changes in the political system. On one hand the hospital suffered relatively large damage due to bombing attacks during the war and on the other it had to face numerous staffing problems, especially with a lack of physicians and trained nursing staff (from 1948 an executive order entered into force forbidding the nursing nuns from performing nursing care in hospitals). The change in the political system required the management of the hospital to be taken over by an individual who enjoyed the political, professional and economic trust of the then authorities. Based on his engagement during the Second World War, the director, Zmago Slokan, represented a form of guarantee for the political system of that time, which nevertheless wanted the quality-based, professional and economic progress of the hospital. Using his personal characteristics, professional medical and economic knowledge as well as political experience, he was able to manage different tendencies to continue the qualitybased progress of the institution. Thus, he set a proper foundation for its development in the periods that followed, in the Socialist Federative Republic of Yugoslavia as well as in the independent Republic of Slovenia (after 1991). The author discusses the role of the director in the hospital's progress chronologically.

Keywords Zmago Slokan • Post-Second World War period · Development of Maribor General Hospital

\footnotetext{
Prim. Assist. Prof. Dr. G. Pivec, MD, PhD $(\bowtie)$

University Medical Centre Maribor,

Ljubljanska ulica 5,

SI-2000 Maribor, Slovenia

e-mail: zdenka.kidric@ukc-mb.si
}

\section{Introduction}

Zmago Slokan managed the hospital during a difficult time after the Second World War. His colleagues perceived him as a man of wide perspective, a person with a vision and extensive professional knowledge. He was respected among his colleagues on account of his influence, which he enjoyed within society, as well as his social-economic engagement and political experience. He gained additional experience during the Second World War, when he was captured (he was a military physician). Prof. Edvard Glaser wrote the following: "Prim. Zmago Slokan, $\mathrm{PhD}$ was a man of wide perspective and he lived according to the principle 'Live and let live'. He was attentive to all that was good" [1].

Among numerous tasks regarding the function and development of the hospital (immediately after the Second World War) concern for professional development was also a part of the management. He supported professional training as well as cooperation at professional meetings and congresses both at home and abroad. He continued to purchase professional literature and introduced the awarding of publishing engagement/activities. This improved professional medical work with patients. Within material and financial resources he was dedicated to purchasing new medical equipment, with emphasis placed on introducing new methods of treatment.

The concept of the hospital's status as "the highest curative institution along the northern border", performing "subclinical services" (the term was probably coined by Dr. Slokan to distinguish it from the medical hospital in Ljubljana) and a learning base of the medical faculty in Ljubljana stems from the Slokan period. These goals were realised after his death in the 1970s and 1980s [2].

This was the foundation to realise the idea of establishing the Faculty of Medicine in Maribor. The project was realised in 2004. In 2007 the second Slovenian medical centre was established. Proof of his mentality can be 
seen from an article at the beginning of the Proceedings of Maribor General Hospital, entitled Na pot! [2]. The proceedings were published at the 100th anniversary of the hospital's existence in Maribor. An addition to the proceedings is a letter to the editor-in-chief of the proceedings by Prim. Eman Pertl [3].

\section{Life journey}

Herman (he changed his Christian name in later years to Zmago) Slokan was born on 15 April 1915 in Trbovlje. His father Filip was a miner and later became a mining inspector. He retired in 1934. His mother Alojzija came from a rural environment. Both parents passed away suddenly, his mother in 1933 due to heart disease and his father in 1943 because of a stroke [4]. The oldest brother Filip was later a teacher in Trbovlje, his brother Karel was a well-known mining engineer and professor emeritus and professor at the University of Ljubljana, [5] and his brother Valter was a mechanical engineer in Trbovlje.

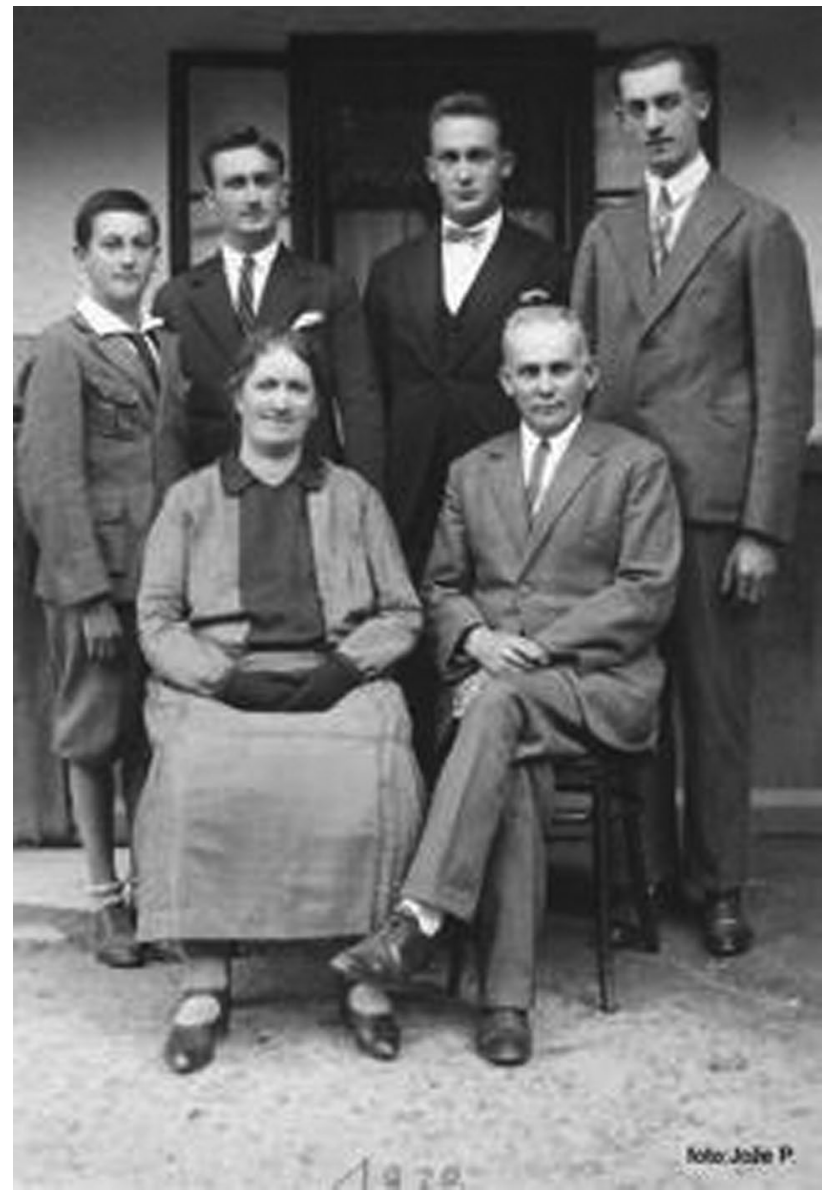

The Slokan family in 1929

In Trbovlje in 1926 Herman completed 5 grades of elementary school and 4 grades of modern secondary school and received his secondary education certificate in 1930.
After passing the entrance exam, he attended the "Third Gymnasium" in Ljubljana and graduated in 1935 [6].

After graduation he began the study of medicine at the partial Medical Faculty in Ljubljana and finished five semesters with a first rigorous exam and continued his studies in Belgrade, where he passed all the exams by March 1941 [6].

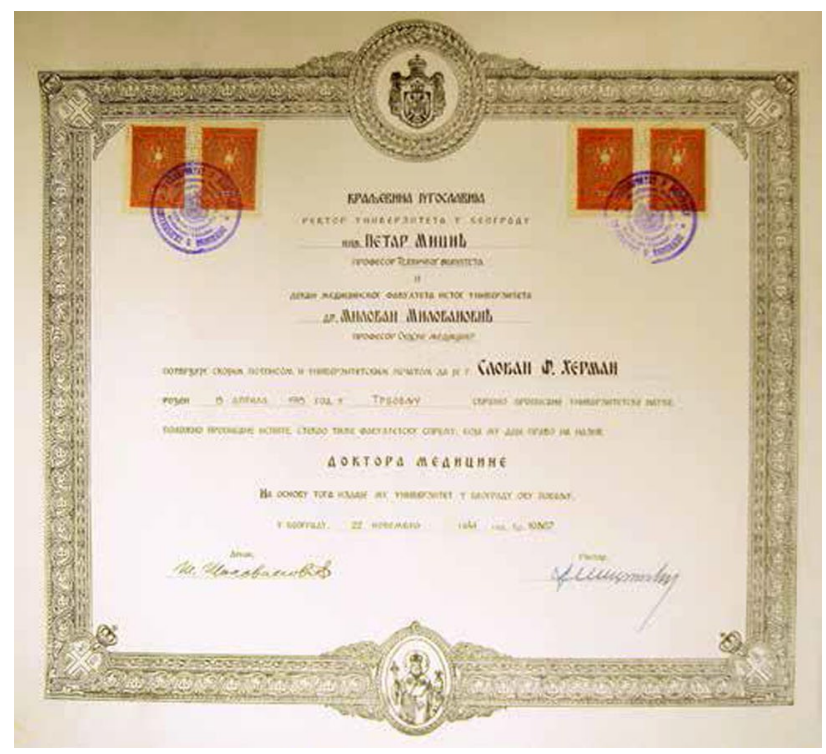

Degree of MD from Medical Faculty Belgrade

Immediately after Germany's attack on the Kingdom of Yugoslavia and its consequent capitulation, he went back to Trbovlje "where I had job and lived with my father until I managed to get an official degree from Belgrade in November 1941" [6].

At the beginning of 1941 (5 January 1941), he received employment as a physician at the mining hospital in Trbovlje and worked across different departments until 31 October 1943. At the same time, he worked in the afternoons as a general physician at an office with social security coverage. As a physician of general practice he was transferred by an order on 1 January 1943 to Hrastnik to work as a mining physician and a physician for the glass factory Steklarna Hrastnik until he voluntarily joined the partisans on 15 April 1944 [6].

Prior to his departure to join the partisans he actively cooperated from October 1942 with the resistance movement by collecting money, sanitary material and colleagues and at the same time cooperated in the field treatment of wounded partisans. He collaborated with numerous activists from this field. At that time he started using the Slovenian name Zmago consistently and made it official after the war, making him mostly known afterwards by this new name [6].

During the National Liberation Struggle he first became a member of the Kamniško-zasavski detachment which was directed by the headquarters of the fourth operative zone. The headquarters of the fourth operative zone was responsible for the organisation and command of the partisan army in the southern part of Styria and Carin- 
thia and Prekmurje (north of the river Sava). As early as 6 May 1941, he was appointed as a warden of the hospital post P2 on the eastern side of Pohorje. He performed this responsible job until the liberation in May 1945.

During this period, he met his future wife Vida Urbanc from Lehen on Pohorje. According to his data she completed secondary modern school in Maribor and the Legat course in sales (commercial course). During the occupation she lived on Pohorje, for a while she was imprisoned in Graz and then joined the partisans in 1944 as an old field activist and informer. Until the liberation, she worked as a nurse at a partisan hospital, Zaklon [7]. After the liberation, they married and in 1946 their son Samo was born. He was a well-known radiologist in Maribor [6]. Slokan mentions the Urbanc family, residing at Lehen 17, in relation to the so-called "Pohorje affair" (from the autumn of 1943 to the spring of 1944), during which more than 50 recruits who had joined the partisans were pardoned out-of-court (52 identified victims). Around New Year's Eve in 1944 some of these cases happened on the aforementioned farm; however, it is necessary to stress that the Urbanc family and Zmago Slokan, who came to Pohorje in June of 1944, had no connection to these events [7]. Dr. Samo Slokan passed away suddenly in 2014 due to a heart condition.

After the Second World War, Zmago Slokan came to Maribor together with the wounded soldiers, where the Headquarters of the Maribor Military District appointed him as the warden of a military hospital. First he had to establish the non-existent hospital and only then, under difficult circumstances, did he begin his work [6].

He kept this function in Maribor until January 1948 when he was transferred to Ljubljana and appointed as the warden of the Chief Military Hospital. He continued to perform his duties as a warden until March 1948, when he was diagnosed with a heart condition. He was treated for almost 2 years in Zagreb. After his treatment and rehabilitation, the Central Military Medical Committee, on 31 March 1950, declared him permanently incompetent to perform military duties, awarded him a $70 \%$ disability rating and discharged him for the Yugoslav People's Army entitling him the rank of Reserve Captain [8].

On 1 April 1950, he gained employment at Maribor General Hospital as a resident for radiology. In 1952, he became the president of the committee for people's healthcare of the City People's Committee Maribor, which, during their meetings, often discussed the renovation and other spatial issues of the hospital [9]. After Prim. Eman Pertl voluntarily left the post of manager, Zmago Slokan took this position on 1 November 1953. In 1955, he passed his board exam in radiology and was given the title Health Counsellor. In 1962, after the retirement of Prim. Mila Kovač, Zmago Slokan assumed the working responsibility as the head of the Radiology Institute [10]. On account of his successful management of the Radiology Institute and Maribor General Hospital, the secretariat for healthcare of the Republic of Slovenia awarded him the title Primarius on 16 December 1966 [11].

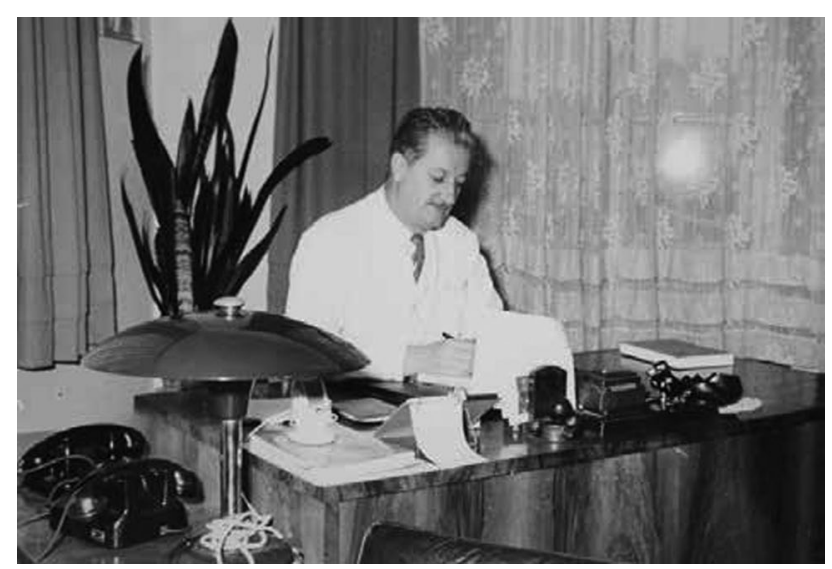

Prim. Zmago Slokan in his office

His health condition deteriorated again in 1968, therefore he underwent cardiac valve surgery in Houston, USA, in October of the same year after consulting with the medical board. He was accompanied by Ivan Krampač. In spite of all this he continued to perform his duties and obligations as director of the hospital until his early death. He died on 25 March 1970 in Opatija, Croatia, where he was receiving treatment and rehabilitation [12].

Ivo Koražija, who by then and especially during the illness of Zmago Slokan, performed duties as deputy director of the General Hospital, took over the management of the hospital as active director on 26 March 1970 [13].

Zmago Slokan was a left-wing intellectual. As a student he worked with the Red Cross and Ferial Association. Later on he was an active member of the left-wing academic society "The Slovene Club" in Ljubljana. He was a member of the Board of the Medical Association. He was one of the co-founders of the left-wing students' association "Youth" in Trbovlje in 1936. He was welleducated and had a good command of German, as evidenced by many documents in the hospital's archives. He also spoke French. Despite his numerous obligations and duties as director of the hospital and head of radiology he performed several important social functions in healthcare settings and political duties in Slovenia and former Yugoslavia. It is remarkable to note that he was a member of the Presidency of the Socialistic Union of Working People and a member of the National Assembly for Social Affairs and Health from 1965 to 1969. Many records show that he publicly advocated the benefits and overall needs of healthcare.

In the obituary that Eman Pertl wrote for Zmago Slokan, he said: "He was a nice associate and a thoughtful interlocutor, and respected by everyone who met him perhaps just by chance. His colleagues appreciated him for his prudence and equity. He never lost his temper. In acute situations he did not act in the heat of passion; he carefully considered every issue and took care of unpleasant things in a way that everybody was comfortable with. We often said: Zmago will take care of it.

We also respected him as a man of ideas and as an economist. He never exaggerated and he always safely 
managed the hospital, moreover he provided other healthcare facilities with healthy ideas. His abundant work should be carefully evaluated and put to life, as he wished. However, unfortunately, he lost this unequal struggle with life, which he loved so much, too early" [14].

The life and work of Zmago Slokan has been solemnly commemorated on several occasions. On the fifth anniversary of his death, the chair of the Medico-historical section of the Slovene Medical Society Eman Pertl prepared his manuscript "Chronicle of the P2 Sector Posts" to be published in the Slovenian Medical Journal [15]. The original of this report, written by Zmago Slokan right after the war in 1947, is kept in the archives of the Republic of Slovenia [16]. On the tenth anniversary of his death, the hospital hosted a grand ceremony, and a similar one on the 70th anniversary of Zmago Slokan's birth and on the 15th anniversary of his death [17]. On the 40th anniversary of his death, the hospital organised a symposium and commemoration, during which the Grand Auditorium in the multistorey hospital building was named after Zmago Slokan [18].

\section{Slokan's influence on the development of the university medical centre, Maribor}

Health policy in Maribor was then formed by the following political and health professionals: Adolf Drolc, Dušan Tomažič, Srečko Koren, Ferdo Hudina, Janez Varl and Matija Nadižar. However, the central role among all participants was played by Zmago Slokan [19].

As director of the hospital, he initiated the professional development and spatial construction of the hospital. He was always striving to build the multistorey hospital building, which required the urban organisation of the entire hospital area. Every piece of land in this area was transferred to be managed and owned by Maribor General Hospital, including premises and land in Pivola, where the hospital's economy was established [20]. Regarding this, Eman Pertl wrote that "construction of the multi-storey hospital building [was] his lifework and a monument to his work, which truly pushed his limits and caused him to burn out" [17]. The erection of the multistorey hospital building started on 26 March 1964. Unfortunately, the construction works were brought to a halt in 1966 due to the economic situation in the Socialist Federative Republic of Yugoslavia (SFRY). The building was not completed until 1976 [21].

During the years after the war the hospital was poorly equipped with little modern equipment and few instruments. In order to achieve effective and coordinated procurement he appointed a working group, which was managed by Franc Rostaher. Drago Kanič, who later replaced Rostaher, noted: "By implementing his ideas of hospital management and carefully considered choice of the purchased valuable medical equipment and special instruments Zmago Slokan enabled the well-balanced development of all hospital departments" [22].
The Department of Radiology received a modern X-ray machine, a Tridoros 4, in 1960 that was a state-of-the art device back then in Slovenia, and the first X-ray television machine, a Pantoskop 2, in 1969.

In 1966, he approved the purchase of a micro phmeter for the maternity ward and an ultrasound machine in 1968 that was the first ultrasound machine purchased in Slovenia, which was quite extraordinary back then. This device enabled the physicians of the maternity ward and the Department of Gynaecology at the Maribor hospital to make remarkable professional development achieving a clinical level far above other university centres within the former Yugoslav states. Regarding this matter, the physicians at the Maribor hospital (Viljem Brumec, Edvard Glaser, Igor Japelj, Niko Jesenovec and Anton Veingerl) wrote a book entitled "Microanalysis of Foetal Blood and Modern Procedures in Obstetrics" that was first published in Slovene in 1971 and in the SerboCroatian language in 1972. The book was dedicated to the late director of the hospital [23].

During the 1960s, Zora Janžekovič discovered a new surgical method for treating burns. Her inventive procedure of tangential excision closed with autologous skin grafts made the author herself, and the hospital, famous worldwide for burns surgery. Surgeons from all over the world visited Maribor to learn this new procedure for treating burns [24].

The Committee for Scientific and Research Work was established in 1964 and its members Milan Černelč, Janko Držečnik, Stojan Jeretin, Janko Berčič, Mirko Birsa and others were in charge of guiding research activities at the hospital. The research was presented in the form of doctoral theses by the following physicians: Draga Černelč (1962), Milan Černelč (1963), Niko Jesenovec (1963) and Bogo Skalicky (1966).

In 1964, Janko Držečnik tested a new open-heart surgery method on dogs using extracorporeal blood circulation that was produced by the Association of Electro-mechanical Engineering TAM Maribor. The device was named Pulmocor. Furthermore, the hospital also actively cooperated with the association in other areas, such as equipment maintenance and spare parts manufacturing [25]. Some research projects that positively influenced the development of departments were performed by Janko Berčič, Eman Pertl, Ivo Mihev and Stojan Jeretin.

Numerous organisational changes were implemented during the Slokan era. In 1961, the Department of Perinatology and Gynaecology was divided into two separate departments. The Surgical Department was a joint department until the 1950s, when it was divided into several units: Traumatology, General Surgery, Urology, Thoracic and Plastic Surgery. The Transfusion Station has become an independent Department for Transfusiology. Similarly, the Central and Biochemical Laboratory grew into an independent department in 1953 and 1954. The Reanimation Centre, established in 1960, became an independent department in 1963 and an independent anaesthesia and reanimation service in 1964 . The 
Medical Rehabilitation Centre started to operate in 1960. After the dissolution of the outpatient clinic, the hospital assumed all of its specialist clinics. Until this, reorganisation patients were centrally admitted, which caused long queues in front of the central office; later patients were admitted at individual departments without having to wait in queues. Moreover, regular on-call duty in every hospital department was introduced during his era [21]. An oncology service was also running during that time; some patients were irradiated in Maribor, severe cases were sent to the Institute of Oncology in Ljubljana by our oncologist Zdenka Runovec. Upon her departure this type of activity completely ceased to operate and today the University Medical Centre Maribor is again intensifying its efforts to establish oncologic treatment [26].

The director of the hospital mainly consulted the advisory staff members and the nurse's council run by the hospital's head nurse Štefka Zalokar, who became a head nurse in 1956 and left the monastery to keep her job at the hospital. According to Štefka Zalokar, she enjoyed the full support and trust of the director despite her worldview. Together they managed to regulate meals for patients and employees; hence, the head nurse visited Switzerland to obtain training in this field. Nursing services started to introduce intensive modernisation processes [27].

Numerous non-medical services necessary for the smooth operation of the hospital were reorganised. Slokan set up services for technical support, planning and analysis, and expanded the Finances and Accounting Department.

In the field of economic management, Slokan consulted financial advisory staff members. After omitting salary categories the hospital introduced reward money on his initiative based on analytical evaluation of the post. The evaluation comprised 12 criteria and was the first of its kind in the Republic of Slovenia [28].

He also appointed a steering board managed by himself in order to publish a hospital gazette called "Naša bolnišnica" (Our Hospital). The gazette was first published in 1976, after his death and is a useful source of information regarding the development of the then Maribor General Hospital [29].

Zmago Slokan also took an active part in solving many of the social problems of his employees. They started to build a block of 42 flats for employees in the vicinity of the hospital in 1959. Later, the hospital acquired an additional 121 flats and its own vacation home on the island of Mali Lošinj. Subsequently, further capacities were acquired on the islands of Krk and Pag, and in the Pohorje Mountains. By adopting these measures, in the spirit of truly existing socialism, he tried to improve employees' satisfaction and strengthen their sense of belonging to Maribor General Hospital.

Despite his numerous obligations as director of the hospital and work in many other organisations he continued his part-time work as a radiologist. He was an important influence by being such a good role model for his employees; therefore, he was respected by his associates.

\section{Conflict of interest}

The author declares that there are no actual or potential conflicts of interest in relation to this article.

\section{References}

1. Glaser E Ob podpori in s pomočjo prim. dr. Zmaga Slokana do sklada za izgradnjo Splošne bolnišnice Maribor, organiziranega zbiranja papirja, zbiranja zgodovinskega gradiva naše bolnišnice v slikah, snovanja zdravstvenih postaj v okolici Maribora in osamosvojitve oddelka za transfuziologijo naše bolnišnice. Naša bolnišnica. 1986;10(2):13-4.

2. Slokan Z Na pot! In: Pertl E, editor. Zbornik Splošne Bolnišnice v Maribor: 1799-1959, 1855-1955. V Mariboru: Splošna bolnišnica, 1959. pp. 5-6.

3. Maribor UKC, Photo lab, letter by Zmago Slokan to the editor-in-chief of the Proceedings of Maribor General Hospital, 1959 to Eman Pertl with instructions and acknowledgement for the preparation of the proceedings.

4. Archives of UKC. Maribor, Personnel.

5. Karel S. Slovenika: Slovenska nacionalna enciklopedija. Ljubljana: Mladinska knjiga; 2011.p. 1323.

6. Autobiography by Dr. Zmago Slokan. Archives of the UKC Maribor, 1964.

7. Štesl J. Pohorska afera. Ljubljana: Študijski center za narodno spravo; 2009.

8. Pivec G. Personal narration of Samo Slokar to the author.

9. Maribor PAMfondOLO. Minutes of the 7. Regular session of the Board of People's Health MLO Maribor, 9 January 1953.

10. Letter to the HR. Committee of the General Hospital (SBM) 74/62 3. 4. 19, Application for the Tendering Committee SBM 5. 4. 1962, arhiv UKC Maribor. Appointment Decision for the Head of Radiology Institute 04-4/1117, 8. 6. 1962, Archives of UKC Maribor.

11. Awarding the title. "Primarius"; Consent on the Proposal of the Republic Health Secretariat SRS. Archives of the UKC Maribor.

12. Personal file of Dr. Zmago Slokan. UKC Maribor Archive.

13. Letter to the Hospital Council suggesting Ivo Koražija for acting director of the General Hospital, 27. 3. 1970. UKC Maribor Archive.

14. Pertl E. Direktor prim. dr. Zmago Slokan: nekrolog (19151970). Večer, 26. 3. 1970; p. 3.

15. Slokan Z. Kronika postojank sektorja "P 2". Zdrav Vestn. 1975;44(3):109-10, 184-5.

16. Archives SIAS. 1860. Slovenske vojne partizanske bolnišnice. Archive box No. 85, Unit 963.

17. Pertl E. Speech on Memorial "70th Anniversary of birth and 15th Anniversary of death of Prim. Dr. Zmago Slokan", Maribor, 19. 12. 1985. Archives of the UKC Maribor.

18. Borko E, Pivec G. Delo in stremljenje ravnatelja prim. dr. Zmaga Slokana. Lecture. Symposium "Življenje in delo prim. dr. Zmaga Slokana - ravnatelja SBM 1953-1970", UMC Maribor, 9. 12.2010.

19. Malešič M. Prim. dr. Zmago Slokan-naš vzor in vodnik. Organizacijska in upravljalna dejavnost SBM po smrti prim. dr. Zmaga Slokana. Naša bolnišnica. 1986;10(2):11-2.

20. Rant F. Prim. dr. Zmago Slokan in njegovo sodelovanje $\mathrm{z}$ družbenopolitičnimi telesi v Mariboru. Naša bolnišnica. 1986;10(2):15.

21. Glaser E. Pregled razvoja celotne bolnišnice in njenih skupnih služb: 1955-1959. In: Pertl E, Držečnik J, editors. Zbornik Splošne Bolnišnice v Mariboru-II: 1955-1985. Maribor: Obzorja; 1991. pp. 7-32. 


\section{editorial}

22. Kanič D. Sodelovanje s prim. dr. Zmagom Slokanom pri izbiri in nabavi dragocene medicinske aparature in specialnega instrumentarija za Splošno bolnišnico Maribor. Naša bolnišnica. 1986;10(2):12.

23. Brumec V.et al. Mikroanalize fetalne krvi in novejši postopki v porodništvu. V Mariboru: Splošna bolnišnica; 1971.

24. Derganc M. Letter to Zmago Slokan, 3 June. 1960. Archives of the UKC Maribor.

25. Antonič J. Oddelek za torakalno kirurgijo. In: Toplak C, editor. Splošna bolnišnica Maribor: 1799-1999. Maribor: Splošna bolnišnica; 2001. pp. 69-73.
26. Pivec G. Strateški razvoj UKC Maribor 2001-2015, p. 30-1 and 2015-2019, p. 25-6.

27. Pivec G. Personal narration of Štefka Zalokar to the author.

28. Archives of the General Hospital Maribor, Financial reports. Dpt of Financial and Accounting.

29. Borko E Kratka zgodovina glasila “Naša bolnišnica”. Naša bolnišnica. 2014:15(3):21-4. 